\title{
Liberalization of parallel imports regulations and marketing strategies of international corporations.
}

\author{
Jacques Picard \\ Université du Québec à Montréal. \\ Peres Academic Center, Rehovot
}

INTRODUCTION

Two recent phenomena have considerably challenged the classical model of products diffusion abroad, i.e. the selection of an exclusive distributor in a foreign country, whose task is to commercialize successfully an imported product.

The first one is the increased tolerance by many states for parallel imports also known as grey products.

The second is the rapid augmentation of international internet selling to individuals and institutions in foreign markets.

This article will describe the phenomena, its consequences, and the way to confront the raised challenges.

The debate around parallel imports:

A product manufactured by a single manufacturer in a particular location, might very well, although identical, be priced differently by exclusive distributors in different countries.

This might be due to different demand price curves, product positioning strategies, currency movements, etc...

It is then tempting for a trader to take advantage of the price gap, by buying the product in the lower price market, and sell it in the higher one. This is called parallel import because the product is not sold by the authorized dealer.

One of the main objections to this practice is based on the argument of "free riding": the parallel exporter (grey marketer) takes advantage, without contribution of its own, of the efforts and investments of the official distributor, who developed the reputation and the goodwill attached to this particular brand in that market.

This in turn could discourage would-be or actual distributors to invest in market development, since the benefit of enjoying later on, a monopolistic position for this particular brand, will not be concretized. Ultimately the product producer could be hurt by a consequential lower level of sales in that country.

That is why obstacles to grey marketing were put in place in legislations of some countries.

\section{DEVELOPMENTS IN PARALLEL IMPORTS REGULATIONS}

It is important to distinguish two issues when dealing with grey goods. 
The first one is the fact that customers could be misled, when buying those goods, into believing that they will receive the same product, with the same warranties and service as if they bought it through authorized channels.

Even in jurisdictions where parallel imports are tolerated, courts have established that customers should never be confused and therefore have to be informed that what they are buying is or might be different, either in its physical form or in the associated warranties or after-sale services, from the product imported through the official distributor. ${ }^{1}$

The second issue deals with the question of legitimacy of parallel imports, even though the consumer is well aware of the nature and the source of the product he buys, and its limitations in terms of associated services.

The main question behind this issue is whether trademark and patent protections are similar in nature.

In both cases the "Exhaustion of rights doctrine" exists. This means that once a product has been legally sold there cannot be any impediment to the resale of that particular product, whatever the intellectual property right (patent, trademark, copyright etc...) attached to it.

The question is whether the exhaustion doctrine applies strictly on a national level, or does it also apply internationally.

For patents and copyrights, it could be broadly affirmed that only the national exhaustion doctrine applies, and therefore the exclusive owner or licensee of such an intellectual property right is perfectly entitled to prevent the sale of a protected product in the country or countries where it holds such a right, even though, it was sold in a foreign state in a perfectly legal way.

This is not so simple for trademark rights, because of the lack of consensus on its nature and purpose.

For some, the solely objective of trademark legislation is to indicate the origin of a good in order to avoid a situation in which a person would buy a product thinking it has been manufactured by one producer, while in fact it was supplied by another.

In that case, as long as there is no confusion on the origin of the purchased product there is absolutely no reason to prevent its sale.

For others trademark protection should be territorial, as other intellectual property rights, and the owner of such a right should be entitled to prevent the sale of its products by unauthorized dealers even though this product was acquired legally in another country.

1 See for example: In the United States Lever Bros. Co. v. U.S., 981 F.2d 1330 (D.C. Cir.1993); In Canada: Consumers Distributing Co. v. Seiko, [1994] 1 S.C.R. 583; In Israel: Swissa v Tommy Hilfiger Licensing LLC (CA $7629 / 12$ and 8846/12, November 16 2014), 
So far no international agreement has been reached on the international exhaustion of rights doctrine (or universality doctrine), as it is explicitly stated in Part I of the World Trade Organization's Agreement on Trade-Related Aspects of Intellectual Property rights. ${ }^{2}$

Therefore differences do exist between different jurisdictions.

\section{a. The United States of America.}

In the judgment A.Bourgeois v. Katzel ${ }^{3}$,the Second Circuit Court of Appeal held that in matters of trademarks the universality doctrine (international exhaustion) did apply.

Following that decision the United States congress passed an amendment to the Tariff Act, in order to limit its consequences. ${ }^{4}$

Nevertheless, the U.S. Customs Service took a very restrictive approach to the amendment. That approach was sanctioned by the Supreme Court in K-Mart Corp. v. Cartier. ${ }^{5}$

In parallel, however, the Supreme Court ${ }^{6}$ reversed the court of appeal decision in $\mathrm{Katzel}^{7}$, and seemed to adopt, on the basis of the U.S. Trade Mark Act , the territoriality doctrine (as opposed to the universality doctrine).

This should have tremendously limited the legal access of grey products in the U.S. . Nevertheless subsequent decisions by different U.S. Courts of Appeals ${ }^{8}$, have seriously restricted the effect of the Supreme Court Katzel Decision' 9 .

In conclusion, although there is still a certain level of ambiguity in the precise legal situation in the U.S., it could be asserted that in spite of the Trademark and Tariff legislations, there are few obstacles to the entry of genuine parallel imports in the U.S. market.

\section{b. The European Union.}

It is important to realize that in the European Union, there is a difference between the legal status of parallel imports within the Union, and when the grey product originates from outside. In the first instance, on the basis of Article 85 of the Treaty establishing the European Community (Treaty of Rome), the European Court of justice ${ }^{10}$ in 1966 decided that an exclusive distribution contract in one country was to be prohibited, as a hindrance to competition from the rest of the Community.

\footnotetext{
2 Article 6

"Exhaustion

For the purposes of dispute settlement under this Agreement, subject to the provisions of Articles 3 and 4 nothing in this Agreement shall be used to address the issue of the exhaustion of intellectual property rights."

3275 F.539 (2d Cir.1921)

${ }^{4}$ Chapter 356, s.526, 46Stat. 763 (1922)

5486 U.S. 281 , (1988)

6260 U.S. 689 , (1923)

7 Supra, footnote 3

8 In particular Weil Ceramics and Glass Inc. v. Dash, 878 F 2d 659 (3 ${ }^{\text {rd }}$ Cir. 1989)

${ }^{9}$ Supra, footnote 6.

10 Etablissements Consten S.A., R.L. and Grundig-Ver Gmbh v. E.E.C Commission, ECLI: EU: C: 1966:41.
} 
A few years later, in 1971 the same Court ${ }^{11} t$ determined that parallel imports could not be prevented on the basis of Article 30 of the Treaty, since it would otherwise consists in a restriction of imports or exports.

Since then the exhaustion of rights doctrine is (with exceptions in particular cases) the rule in the European Union, but on a regional basis only.

This principle has been reiterated formally in Article 7 of the DIRECTIVE 2008/95/EC OF THE EUROPEAN PARLIAMENT AND OF THE COUNCIL of 22 October 2008 to approximate the laws of the Member States relating to trade marks. ${ }^{12}$

The situation however is different when parallel imports originate from outside the European Union, in which case a trademark owner is entitled to prevent the entrance of a grey product coming from outside the Union. ${ }^{13}$ In other words In the E.U. it is neither the International nor the National exhaustion but a Regional exhaustion of rights doctrine that applies.

\section{c. Canada.}

Although the Supreme Court of Canada had rejected in 1994 a request for prevention of entry of grey products in the Seiko ${ }^{14}$ Case. It was on the basis of a passing-off proceedings, and not a trademark infringement action.

A certain amount of uncertainty, therefore, remained regarding the legality of parallel importation. This was put to end in 1996 with the Federal Appeal Court decision in Smith \& Nephew Inc. $v$ Glen Oak ${ }^{15}$ that established the principle of universal exhaustion of rights doctrine in Canada.

Further attempts by plaintiffs to reduce the effect of that judgment by either pleading an exception for products exported from Canada ${ }^{16}$, or because registered as trademarks by the Canadian distributor ${ }^{17}$ failed.

Similarly other countries (Australia, Hong Kong, Israel etc...) have also adopted the universal exhaustion of rights doctrine.

\section{DEVELOPMENTS IN INTERNET (ONLINE)SHOPPING}

On November 30, 2015 CBC News was posting:" More U.S. shoppers reported making purchases online over the Thanksgiving weekend than the number who shopped in stores, according to the National Retail Federation."

Alibaba "is on track to become the world's first e-commerce firm to handle $\$ 1$ trillion a year in transactions"18

\footnotetext{
11 Deutsche Grammophon GmbH v. Metro-SB Grossmarket GmbH \& Co. KG , ECLI:EU:C:1971:59

12 Official journal of the European Union L 299/29

13 Silhouette International Schmied GmbH \& Co. KG v. Hartlauer Handelsgesellschaft mbH, [1998] E.C.R. C-395/96

14 Supra. footnote 1

15 [1996] 3 F.C. 565

16 Coca-Cola Ltd. v. Pardham (Universal Exporters, [1999] C.F.A. n.484

${ }^{17}$ Havana House Cigar \& Tobacco Merchants Ltd v. Skyway Cigar Store, [1999] C.F.A n.1749

18 The Economist March 23rd 2013.
} 
Those (with E-Bay and Amazon's huge amount of reported sales ) are just illustrations of the extent of online shopping increase over the years. ${ }^{19}$ The phenomenon has been examined under several angles in the academic world, by marketing scholars. More particularly the question of what factors affect online consumer behavior ${ }^{20}$, has centralized much research efforts.

A big part of those online transactions is not domestic but sales from one country to another. Business-to consumer internet commerce reached $\$ 230$ billion in 2014 , according to a report from Accenture and AliResearch companies. ${ }^{21}$

The question of the legality of such activities, in term of intellectual property rights has been investigated by some authors ${ }^{22}$ especially as far as copyrights are concerned, since the universal exhaustion of rights doctrine does not apply in that case. However since that is the doctrine that more and more prevails in the trademark domain, as it was shown in the above section, the rapid increase of online imports shopping just comes to exacerbate the phenomenon of parallel imports.

This brings into serious question the feasibility of keeping with the traditional model of granting or accepting an exclusive dealership in a foreign market. This in turn triggers the issue of how foreign markets will be developed in the future if no local business is ready to invest important efforts and money into it.

\section{MARKETING CHALLENGES}

One potential consequence of the loss of market power for exclusive distributors due to the two factors mentioned in the previous sections' could be a shift by them from a "pull" toward a "push" marketing strategy.

In other words, rather than investing vast amount of money in mass communication in order to "pull" the customers, they will rather increase the profit margins of the retailers or other

\footnotetext{
19 “Global B2C Ecommerce Sales to Hit \$1.5 Trillion This Year Driven by Growth in Emerging Markets” E-Marketer February $3^{\text {rd }} 2014$

20 See for example:
}

Shah, A. B., \& Rao, M. G. (2014). A study on factors affecting online shopping behavior in Gujarat. International Journal of Applied Services Marketing Perspectives, 3(2), 964-968.

Pawar, S. S., More, D. K., \& Bhola, S. S. (2014). Analysis of factors influencing online service buyers. International Journal of Applied Services Marketing Perspectives, 3(3), 1146-1151.

Akroush, M. N., \& Al-Debei, M. (2015). An integrated model of factors affecting consumer attitudes towards online shopping. Business Process Management Journal, 21(6), 1353-1376.

Kaur, G., \& Khanam Quareshi, T. (2015). Factors obstructing intentions to trust and purchase products online. Asia Pacific Journal of Marketing and Logistics, 27(5), 758-783.

Karimi, S., Papamichail, K. N., \& Holland, C. P. (2015). The effect of prior knowledge and decision-making style on the online purchase decision-making process: A typology of consumer shopping behaviour. Decision Support Systems, 77, 137.

21 Alizilia June 11, 2015

22 See for example:

Saravia, V. J. (2008-2009). Shades of Gray: The Internet Market of Copyrighted Goods and Call for the Expansion of the First-Sale Doctrine. Southwestern Journal of International Law 15(2), 383-418.

Angelopoulos, C. (2015). Sketching the outline of a ghost: The fair balance between copyright and fundamental rights in intermediary third party liability. Info : The Journal of Policy, Regulation and Strategy for

Telecommunications, Information and Media, 17(6), 72-96. 
intermediaries in the marketing channel in order to encourage them to "push" the imported product to the clients.

That way they will reduce their initial investment (and risk), while decreasing their own profit margin.

This kind of strategic change might, however, be detrimental to the total sales of the exporter in that market. Indeed, if a distributor who would have chosen a pull strategy, declines to do so just out of fear of parallel imports, it might well be that the push policy that is instead undertaken is not optimal as far as total market sales are concerned. That could lead to an opportunity cost for the foreign manufacturer.

One of the ways to minimize that problem could be to shift the market communication task from the importer (distributor) to the exporter (producer) of the foreign product. This will, obviously, increase the cost of entry to potential exporting companies, but the investment could be recovered by charging higher prices to the local dealer (reducing therefore its profit margin per unit sold), who in turn will benefit from the greater market exposure created by its foreign supplier.

Another possibility that is open to multinational companies is to push as much as possible for greater similarity in their product pricing in the different country-markets they supply. This is, however, not always practical, because of the constant currencies fluctuations and the different economical and cultural situations prevailing in various markets.

Some international companies have found other creative ways of circumventing the problem. For example, a smart phone manufacturer provides for a two years guarantee for its products if bought through the official distributor in that country.

This tactic would obviously not be very efficient for perishable products, or for those that do not need a warranty, but the fundamental idea of providing some additional value or benefits to those articles sold through the authorized dealer could be extended to other product categories.

\section{CONCLUSION}

Because of the difficulty to legally prevent parallel imports which have intensified crossborders on-line shopping ,the method of entry to international markets through a contract with an exclusive distributor, seems to have recently taken a serious hit.

Obviously, not every industry is similarly affected by this trend. Manufacturers of products necessitating long-term after-sale services and warranties, will be less impacted by the phenomenon.

Creative ways of developing a market in foreign countries will have to be established in order to substitute or to supplement one of the most traditional market penetration methods. 